\title{
Penentuan Harga Jual Kerupuk Bawang Berdasarkan Pengadopsian Metode BOW dan Analisa Lapangan
}

\author{
(Sentra Produksi Kerupuk Lingkungan Mangli, Kabupaten Jember)
}

\author{
Rizal Perlambang CNAWP ${ }^{1 *}$, Alwan Abdurahman ${ }^{1}$ \\ ${ }^{1}$ Department of Agribusiness Management, Politeknik Negeri Jember \\ *rizal_perlambang@polije.ac.id
}

Submitted: 08 Feb 2021

Accepted: 29 Apr 2021

Published: 28 Jun 2021

\begin{abstract}
ABSTRAK
Penelitian ini dilakukan untuk menganalisis dan menguji penentuan koefisien harga satuan upah, bahan dan alat berdasarkan pengadopsian metode BOW (Burgerlijke Openbare Werken). Penelitian ini juga dilakukan untuk mengembangkan pengadopsian metode dalam perhitungan koefisien harga satuan dalam proses produksi. Temuan penelitian ini menunjukkan kontribusi penting koefisien dasar sebagai acuan atau standart perhitungan dalam manajemen produksi, serta kesesuaian produksi yang berada di lapangan. Perolehan harga pokok produksi dan harga jual yang didapat itu lebih terperinci dan akurat atas standart produksi yang telah diperoleh dalam penentuan koefisien harga satuan.
\end{abstract}

Kata kunci: bow, koefisien harga satuan, harga pokok produksi, penentuan harga jual

\section{ABSTRACT}

The study is done to analyze and test the determination of the unit price, materials and equipment based on adopting a method of BOW (Burgerlijke Openbare Werken). The research also implemented to develop adopting methods in calculation the unit price during the production process. The findings of the research indicated important contributions the basic as nontechnical standart management thinks in production, and conformity production in the field. In the cost of goods production and the selling price obtained is detailed and accurate standart has received top production in the determination of the unit price.

Keyword: bow, unit price coefficient, cost of goods sold, selling price determination

\section{Pendahuluan}

Saat ini Indonesia sedang dalam tahap perkembangan usaha yang begitu pesat. Perkembangan kondisi ekonomi yang ada di Indonesia saat ini telah memberikan kesempatan dan peluang usaha yang seluas-luasnya bagi perusahaan industri untuk meningkatkan jumlah produksinya dalam rangka memenuhi kebutuhan konsumen. Perkembangan pasar yang semakin global inilah yang akhirnya membuat persaingan usaha di Indonesia semakin ketat.

Semakin derasnya arus teknologi dan informasi menuntut setiap perusahaan untuk dapat bertahan dalam persaingan global. Perkembangan teknologi dalam pasar global ini akan berdampak salah satunya pada perusahaan manufaktur. Perusahaan dituntut untuk dapat memanfaatkan teknologi guna menunjang kinerja perusahaan dan proses produksi. Setiap perusahaan, yang dalam hal ini khususnya perusahaan manufaktur, sebelum melakukan aktivitas terutama produksi membutuhkan informasi yang berhubungan dengan proses produksi, seperti informasi total biaya yang dibutuhkan, jumlah produksi serta barang yang dipergunakan. Untuk itu diperlukan suatu bagian yang menghasilkan informasi yang dibutuhkan yaitu informasi akuntansi yang menyajikan informasi mengenai pendapatan total, biaya total dan aktiva total baik di masa lalu maupun di masa yang akan datang. 
Di dalam penganalisaan informasi akuntansi , pada suatu perusahaan selalu berkaitan dengan objek informasi yang dapat berupa produk, aktivitas, departemen, atau divisi perusahaan sebagai objek keseluruhan. Biaya produksi meliputi biaya-biaya yang terdiri dari pembelian bahan baku, upah tenaga kerja yang diperlukan serta biaya-biaya yang termasuk dalam biaya overhead pabrik. Sedangkan penentuan biaya produksi tersebut sangat berpengaruh terhadap harga jual produk. Apabila harga produksi besar tentunya harga jual produk tersebut juga harus tinggi untuk mendapatkan laba yang diharapkan.

Sebagian besar perusahaan pada umumnya bertujuan untuk mendapatkan keuntungan yang optimum. Untuk memperoleh keuntungan atau laba yang optimum, khususnya untuk perusahaan manufaktur, peranan perhitungan harga pokok produksi dan perhitungan harga jual sangat berperan, hal ini berkaitan dengan persaingan harga jual produk dengan perusahaanperusahaan lain yang sejenis.

Perhitungan harga pokok produksi adalah hal yang perlu diperhatikan dalam penentuan harga jual suatu produk. Perhitungan harga pokok produksi yang tepat dan akurat merupakan hal yang perlu dilakukan oleh setiap perusahaan, karena tanpa adanya perhitungan harga pokok produksi yang tepat dan akurat, perusahaan manufaktur yang bersangkutan akan mengalami masalah dalam penentuan harga jual suatu produk. Bagi perusahaan dengan tujuan mencapai laba optimum, harga jual dan realisasi biaya produksi berpengaruh sangat besar terhadap ukuran kebehasilan pencapian tujuan perusahaan yang bersangkutan dan memenangkan persaingan yang semakin tajam dengan perusahaan lain yang sejenis. Salah satu faktor yang sangat penting untuk mencapai hal tersebut adalah dengan mengefisienkan biaya produksi serendah-rendahnya sehingga akan memperbesar laba.

Ketidaktepatan perhitungan harga pokok produksi dan penetapan harga jual akan memberikan dampak kerugian bagi perusahaan. Oleh karena itu, diperlukan perhitungan yang mampu menganalisa harga satuan produksi atas dasar koefisien yang muncul dari rasio perbandingan prestasi tenaga kerja, penggunaan bahan, peralatan dalam suatu produksi, yaitu Analisa BOW (Burgerlijke Openbare Werken) 28 Februari 1921, No. 5372 A. Keunggulan dari Burgerlijke Openbare Werken terletak pada penggunaan koefisien dari setiap biaya berdasarkan profesionalisme kerja, penggunaan bahan dan kebutuhan peralatan.

Selain mengadopsi analisa BOW, penggunaan analisa lapangan juga sangat penting dalam perhitungan perolehan harga satuan produksi. Kecenderungan dalam analisa lapangan itu terdapat pada cara memperoleh data-data langsung dari lapangan dan kemudian di analisa sendiri yang didasarkan atas pengalaman-pengalaman terdahulu dalam menyelesaikan suatu kegiatan produksi.

Metode Burgerlijke Openbare Werken dan analisa lapangan dapat diterapkan pada perhitungan harga satuan dari segala bidang kegiatan produksi maupun konstruksi dan skala perusahaannya. Analisa harga satuan produksi yang tepat berpengaruh pada perhitungan harga pokok produksi dan penetapan harga jual yang tepat pula. Dengan penetapan harga jual produk yang tepat, perusahaan dapat bersaing dengan kompetitornya sehingga dapat terus mempertahankan dan mengembangkan usahanya.

Konsep biaya merupakan konsep penting yang ada dalam akuntansi biaya dan akuntansi manajemen. Pada perusahaan informasi biaya digunakan untuk proses perencanaan, pengendalian dan pembuatan keputusan. Biaya sendiri merupakan pengorbanan sumber ekonomi yang diukur dalam satuan uang untuk memperoleh barang atau jasa yang diharapkan dapat memberikan manfaat baik di masa sekarang ataupun di masa yang akan datang. Dalam penyajian laporan keuangan biaya dibagi menurut fungsi-fungsi organisasi yaitu kelompok biaya pokok penjualan, biaya penjualan, biaya administrasi dan umum, serta biaya-biaya non operasi. Terdapat 4 unsur pokok dalam definisi biaya diantaranya biaya merupakan pengorbanan sumber ekonomi yang diukur dalam satuan uang, yang telah terjadi atau yang secara potensial akan terjadi, pengorbanan tersebut untuk tujuan tertentu [1]. Secara garis besar biaya dikelompokkan menjadi biaya pabrik dan non pabrik. Semua biaya yang terjadi di pabrik baik 
yang berhubungan langsung dengan proses produksi maupun tidak, digolongkan ke dalam kelompok biaya pabrik. Aktivitas produksi adalah aktivitas mengolah bahan baku menjadi produk jadi yang dilakukan oleh tenaga kerja, mesin, peralatan, dan fasilitas pabrik lainnya [2].

BOW (Burgerlijke Openbare Werken) adalah suatu ketentuan dan ketetapan umum yang ditetapkan pada tanggal 28 Februari 1921 Nomor 5372 A, pada jaman Pemerintahan Belanda. Analisa BOW biasanya hanya dipakai untuk pekerjaan yang bersifat padat karya dan memakai peralatan konvensional, penggunaan peralatan sederhana yang sampai sekarang masih digunakan dalam menghitung pembiayaan suatu kegiatan (produksi) yang berskala kecil. Namun di dalam BOW juga ada analisa harga satuan pada kegiatan (produksi) yang berskala besar [3] . Menurut John. W. Niron dalam buku yang berjudul Pedoman Praktis Anggaran dan Borongan (Rencana Anggaran Biaya Bangunan), analisis BOW merupakan suatu rumusan penentuan harga satuan tiap jenis pekerjaan. Ada 2 (dua) kelompok koefisien dalam analisa yaitu: pecahan/angka satuan untuk bahan (indeks satuan bahan) dan pecahan/angka satuan untuk tenaga kerja (indeks satuan tenaga kerja). Kegunaannya untuk kalkulasi bahan yang dibutuhkan dan kalkulasi upah yang mengerjakan. Prinsip yang terdapat dalam metode BOW mencakup daftar koefisien upah dan bahan yang telah ditetapkan. Keduanya menganalisa harga (biaya) yang diperlukan untuk membuat harga satuan pekerjaan bangunan. Dari kedua koefisien tersebut akan didapatkan kalkulasi bahan-bahan yang diperlukan dan kalkulasi upah yang mengerjakan [4]. Menurut A. Soedradjat Sastraatmadja menjelaskan penaksiran anggaran biaya adalah proses perhitungan volume pekerjaan, harga dari berbagai macam bahan dan pekerjaan yang akan dilaksanakan. Karena taksiran dibuat sebelum dimulainya pembangunan maka jumlah ongkos yang diperoleh adalah taksiran bukan biaya sebenarnya [5].

Analisa harga satuan produksi adalah suatu hal yang perlu diperhatikan dalam penentuan harga jual suatu produk. Perhitungan harga satuan produksi yang tepat dan akurat merupakan hal yang perlu dilakukan oleh setiap perusahaan.
Bagi perusahaan dengan tujuan mencapai laba optimum, harga jual dan realisasi biaya produksi berpengaruh sangat besar terhadap ukuran kebehasilan pencapian tujuan perusahaan yang bersangkutan. Salah satu faktor yang sangat penting untuk mencapai hal tersebut adalah dengan mengefisienkan biaya produksi serendah-rendahnya sehingga akan memperbesar laba. Perhitungan harga satuan produksi yang dijabarkan dalam perkalian kebutuhan bahan, upah tenaga, dan peralatan dengan harga bahan, standar pengupahan pekerja dan harga sewa/beli peralatan untuk menyelesaikan per satuan produksi. Analisa harga satuan produksi ini dipengaruhi oleh angka koefisien yang menunjukkan nilai indeks bahan, upah tenaga, dan peralatan ataupun satuan kegiatan yang dapat digunakan sebagai acuan/panduan untuk merencanakan atau mengendalikan biaya suatu produksi. Sistem perhitungan dengan menggunakan acuan analisa harga satuan produksi ini diperoleh perhitungan yang lebih terperinci, akurat dan haruslah disesuaikan dengan kondisi lapangan, kondisi alat, dan metode pelaksanaan. Dengan biaya produksi yang lebih akurat kini perusahaan akan mampu menetapkan harga jual produk secara akurat.

Skema harga satuan produksi yang dipengaruhi oleh faktor bahan baku, upah tenaga kerja, dan peralatan [6] dapat dirangkum sebagai berikut:

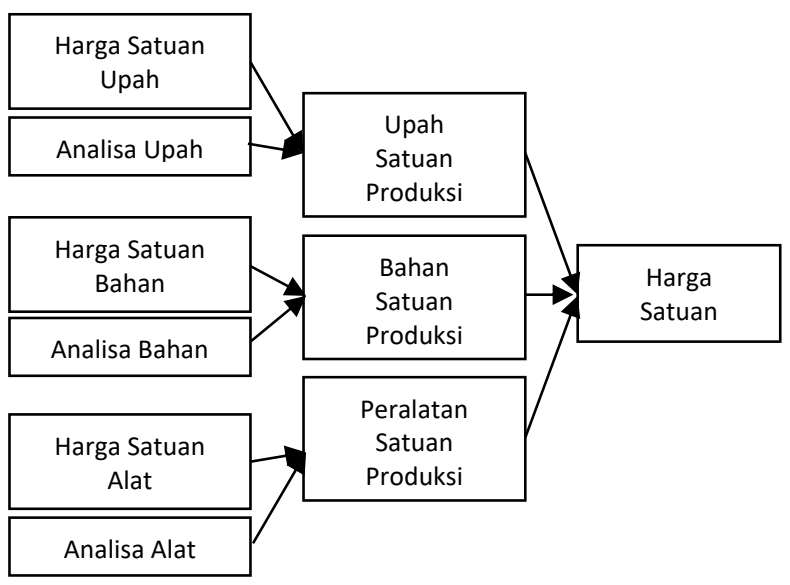

Figure 1. Skema Harga Satuan Produksi

Dalam skema di atas dijelaskan bahwa untuk mendapatkan harga satuan produksi maka harga satuan bahan, upah tenaga, dan peralatan harus diketahui terlebih dahulu yang kemudian dikalikan dengan koefisien yang telah ditentukan 
sehingga akan didapatkan perumusan sebagai berikut.

Upah : harga satuan upah $\mathrm{x}$ koefisien (upah)

Bahan : harga satuan bahan $\mathrm{x}$ koefisien (bahan)

Peralatan : harga satuan alat $\mathrm{x}$ koefisien (peralatan)

Besarnya harga satuan produksi tergantung dari besarnya harga satuan bahan, harga satuan upah dan harga satuan peralatan dimana harga satuan bahan tergantung pada ketelitian dalam perhitungan kebutuhan bahan untuk setiap jenis pekerja dalam menyelesaikan pekerjaan. Harga satuan peralatan baik sewa ataupun investasi tergantung dari kondisi lapangan, kondisi peralatan, metode pelaksanaan.

Harga merupakan salah satu jenis informasi penting mengenai suatu produk yang diterima oleh konsumen. Penetapan harga jual juga berhubungan dengan seluruh tujuan jangka pendek atau sasaran jangka panjang sebuah perusahaan. Penentuan harga jual suatu produk atau jasa merupakan salah satu keputusan penting manajemen karena harga yang ditetapkan harus dapat menutup semua biaya dan mendapatkan laba yang diharapkan oleh perusahaan. Memilih harga yang paling sesuai untuk produk atau jasa yang dihasilkan merupakan keputusan dari manajer yang cukup sulit, karena penetapan harga ini berpengaruh terhadap perkembangan suatu usaha tersebut. Faktor-faktor internal perusahaan yang mempengaruhi kebijakan penetapan harga jual meliputi laba yang diinginkan, faktor produk, dan faktor biaya [7].

Banyak penelitian yang mengkaji tentang penentuan harga jual, namun di setiap daerah tentu memiliki karakteristik harga tersendiri. Selain itu, fokus masalah yang dikaji yakni belum banyak dilakukan oleh peneliti terdahulu terkait dengan pengadopsian metode BOW (Burgerlijke Openbare Werken) dan analisa lapangan. Kontribusi masing-masing jurnal penelitian yang telah disebutkan sebelumnya adalah dalam rangka sebagai bahan untuk menyusun state of the art yakni terkait dengan kumpulan teori, dan referensi baik yang mendukung atau tidak mendukung penelitian. Adapun itu semua dilakukan agar penelitian menjadi semakin kokoh karena dapat dijadikannya sebuah acuan. Dari adanya state of the art dapat diketahui bahwa tidak ada yang secara khusus membahas penentuan harga jual dengan pengadopsian metode BOW (Burgerlijke Openbare Werken) dan analisa lapangan di Lingkungan Mangli Kabupaten Jember, Jawa Timur. Dengan demikian, dapat disimpulkan bahwa penelitian ini tergolong masih baru dan belum banyak dilakukan oleh peneliti terdahulu.

\section{Metode Penelitian}

Penelitian ini termasuk dalam jenis penelitian deskriptif adalah penelitian yang dilakukan untuk mengetahui nilai variabel mandiri, baik satu variabel atau lebih (independen) tanpa membuat perbandingan atau menghubungkan antara variabel satu dengan variabel yang lain [8]. Penelitian yang dilakukan ini merupakan jenis penelitian deskriptif. Penelitian ini menggambarkan tentang data yang diperoleh serta menganalisis data yang sudah ada. Dalam penelitian ini, fenomena atau kejadian yang diamati adalah kondisi proses produksi, penentuan nilai koefisien pada masingmasing komponen biaya pada proses produksi, serta penganalisaan harga satuan produksi berdasarkan pengadopsian metode BOW (Burgerlijke Openbare Werken) dan Analisa Lapangan yang dilakukan dalam rangka penetapan harga jual.

Pengumpulan data primer dilakukan melalui wawancara langsung dengan pihak yang terkait dengan penyediaan data dan informasi yang diperlukan dalam penelitian ini yaitu tentang bahan yang digunakan, upah tenaga, dan peralatan yang dibutuhkan terkait proses produksi. Dalam penelitian ini pihak yang diwawancarai adalah salah satu pemilik perusahaan kerupuk bawang yang memiliki kapasitas produksi terbesar di sentra produksi kerupuk bawang Lingkungan Mangli Kabupaten Jember yaitu Bapak Munjiyat. Pertanyaan yang diajukan telah disusun sebelumnya secara sistematis dan dipandu menggunakan kuesioner yang telah valid dan reliabel. Data sekunder bersumber dari informasi/data yang dimiliki instansi terkait, serta buku literatur, jurnal ilmiah dan/atau berbagai macam bentuk terbitan sebagaimana tercantum dalam daftar pustaka. Teknik analisis data yang digunakan adalah dengan melakukan perhitungan analisa harga satuan produksi dan penentuan harga jual produk 
dengan pengadopsian metode BOW dan Analisa Lapangan.

\section{Hasil dan Pembahasan}

Kerupuk yang dihasilkan haruslah memiliki karakteristik dan kualitas yang baik. Perusahaan kerupuk tersebut setiap kali melakukan proses produksi untuk dapat bertahan dalam pasar. Dalam penelitian ini, pengasumsian data yang dibutuhkan adalah data langsung dari lapangan, ini ditujukan agar data yang dibutuhkan dapat diperoleh dengan jelas dan akurat dalam perolehan nilai koefisien pada setiap aktifitas produksinya. Jumlah produksi yang dihasilkan tetap berdasarkan kapasitas produksi setiap harinya.

\subsection{Pemakaian Biaya Bahan Baku}

Biaya bahan baku merupakan komponen biaya terbesar dalam pembuatan produk jadi. Biaya bahan baku mudah ditelusuri pada setiap unit produk yang dihasilkan, hal ini dikarenakan biaya bahan baku secara fisik akan menjadi bagian dari produk jadi. Sehingga biaya bahan baku dibebankan secara langsung ke proses produksi tanpa melalui alokasi biaya terlebih dahulu. Bahan baku yang digunakan untuk memproduksi kerupuk ini adalah tepung terigu, bawang putih, bawang merah, ketumbar bubuk, merica bubuk, garam, kaldu bubuk, soda kue, seledri, dan air. Dari kebutuhan bahan baku di atas dapat diperinci lagi berdasarkan kebutuhan bahan baku setiap $\mathrm{kg}$ kerupuk dengan menggunakan analisa koefisien bahan baku.

Table 1. Analisa Koefisien Bahan Baku

\begin{tabular}{|c|c|c|c|c|}
\hline \multirow{2}{*}{$\begin{array}{c}\text { Uraian } \\
\text { Tepung terigu }\end{array}$} & \multicolumn{2}{|c|}{$\begin{array}{l}\text { Volume per } \\
\text { Satuan } 1 \mathrm{Kg}\end{array}$} & \multirow{2}{*}{$\begin{array}{c}\begin{array}{c}\text { Volume } \\
\text { Satuan }(\mathrm{Kg})\end{array} \\
0,653967\end{array}$} & \multirow{2}{*}{$\begin{array}{r}\text { Koef./Kg } \\
0,653967\end{array}$} \\
\hline & 0,65 & $\mathrm{Kg}$ & & \\
\hline \multicolumn{5}{|l|}{ Bumbu : } \\
\hline Bawang putih & 10 & Siung & 0,066667 & 0,006023 \\
\hline Bawang merah & 15 & Siung & 0,100000 & 0,008282 \\
\hline Ketumbar bubuk & 3 & Sdt & 0,020000 & 0,002981 \\
\hline Merica bubuk & 0,25 & $\mathrm{Sdt}$ & 0,001667 & 0,000069 \\
\hline Garam & 3 & $\mathrm{Sdt}$ & 0,020000 & 0,023851 \\
\hline Kaldu bubuk & 4 & $\mathrm{Sdt}$ & 0,026667 & 0,002650 \\
\hline Soda kue & 3 & Sdt & 0,020000 & 0,000706 \\
\hline Seledri & 2 & $\mathrm{Btg}$ & 0,013333 & 0,003313 \\
\hline Air & 0,09 & Liter & 0,090000 & 0,090000 \\
\hline
\end{tabular}

Produk yang dihasilkan minimal sebanyak $100 \mathrm{~kg}$ untuk setiap kali produksi setiap hari dengan menghabiskan biaya bahan baku sebesar Rp 7.031,58 dalam satu kg.

Table 2. Analisa Harga Satuan Bahan Baku

\begin{tabular}{lccc}
\hline Uraian & Koef. & $\begin{array}{c}\text { Harga Satuan } \\
(\mathrm{Rp})\end{array}$ & $\begin{array}{c}\text { Jumlah } \\
(\mathrm{Rp})\end{array}$ \\
\hline Bahan baku : & & & \\
\hline Tepung terigu & 0,653967 & $9.500,00$ & $6.212,68$ \\
\hline Bawang putih & 0,006023 & $33.000,00$ & 198,76 \\
\hline Bawang merah & 0,008282 & $36.000,00$ & 298,14 \\
\hline Ketumbar bubuk & 0,002981 & $20.000,00$ & 59,63 \\
\hline Merica bubuk & 0,000069 & $71.500,00$ & 4,97 \\
\hline Garam & 0,023851 & $2.500,00$ & 59,63 \\
\hline Kaldu bubuk & 0,002650 & $30.000,00$ & 79,50 \\
\hline Soda kue & 0,000706 & $84.500,00$ & 59,63 \\
\hdashline Seledri & 0,003313 & $12.000,00$ & 39,75 \\
\hline Air & 0,090000 & 210,00 & 18,90 \\
\hline & Jumlah biaya bahan baku /kg kerupuk & $\mathbf{7 . 0 3 1 , 5 8}$ \\
\hline
\end{tabular}

\subsection{Pemakaian Biaya Tenaga Kerja Langsung}

Tenaga kerja merupakan salah satu faktor produksi yang utama dan selalu ada dalam perusahaan. Tenaga kerja yang bekerja di pabrik atau perusahaan manufaktur dikelempokkan menjadi dua yaitu, biaya tenaga kerja langsung dan biaya tenaga kerja tidak langsung. Tenaga kerja langsung adalah tenaga kerja yang terlibat secara langsung dalam proses mengubah bahan baku menjadi produk jadi. Jumlah tenaga kerja langsung di perusahaan kerupuk ini sebanyak 7 orang dengan rincian 1 orang sebagai mandor, 1 orang sebagai tukang giling, 3 orang sebagai tukang cetak, 1 orang sebagai tukang oven, dan 1 orang sebagai tukang jemur.

Table 3. Analisa Koefisien UpahTenaga Kerja

\begin{tabular}{ccccc}
\hline Uraian & Satuan & Volume & $\begin{array}{c}\text { Volume } \\
\text { Prestasi }\end{array}$ & Koef./Kg \\
\hline Mandor & $\mathrm{OH}$ & 1 & 1 & 0,020833 \\
\hdashline Tukang giling & $\mathrm{OH}$ & 1 & 6 & 0,125000 \\
\hdashline Tukang cetak & $\mathrm{OH}$ & 3 & 18 & 0,375000 \\
\hdashline Tukang oven & $\mathrm{OH}$ & 1 & 6 & 0,125000 \\
\hline Tukang jemur & $\mathrm{OH}$ & 1 & 6 & 0,125000 \\
\hline
\end{tabular}

Biaya tenaga kerja langsung yang dikeluarkan perusahaan sebesar $\mathrm{Rp}$ 2.383,33 setiap satu kg kerupuk. 
Table 4. Analisa Harga Satuan Upah Tenaga Kerja

\begin{tabular}{lccc}
\hline Uraian & Koef. & $\begin{array}{c}\text { Harga Satuan } \\
(\mathrm{Rp})\end{array}$ & Jumlah (Rp) \\
\hline Tenaga kerja : & & & \\
\hline Mandor & 0,020833 & $50.000,00$ & 83,33 \\
\hline Tukang giling & 0,125000 & $40.000,00$ & 400,00 \\
\hline Tukang cetak & 0,375000 & $40.000,00$ & $1.200,00$ \\
\hline Tukang oven & 0,125000 & $40.000,00$ & 400,00 \\
\hline Tukang jemur & 0,125000 & $30.000,00$ & 300,00 \\
\hline \multicolumn{4}{c}{ Jumlah biaya upah tenaga kerja /kg kerupuk } \\
\hline
\end{tabular}

\subsection{Biaya Overhead}

Biaya overhead yang dimaksud adalah biaya-biaya produksi lain yang dikeluarkan perusahaan diluar biaya bahan baku dan biaya tenaga kerja langsung. Overhead terdiri dari berbagai biaya yang tidak secara langsung dapat dihubungkan dengan suatu produk atau sekelompok produk. Dalam perusahaan kerupuk overhead ysng dibutuhkan adalah biaya bahan bakar (sekam). Berdasarkan kebutuhan bahan bakar untuk menghasilkan satu $\mathrm{kg}$ kerupuk dengan menggunakan analisa koefisien overhead.

Table 5. Analisa Koefisien Overhead

\begin{tabular}{ccccc}
\hline Uraian & Sat. & Vol. & $\begin{array}{c}\text { Koef./Hari } \\
100 \mathrm{Kg}\end{array}$ & Koef./Kg \\
\hline Bahan bakar (Sekam) & Zak & 3 & 3,000000 & 0,030000 \\
\hline
\end{tabular}

Jumlah biaya overhead yang dikeluarkan perusahaan kerupuk ini sebesar Rp 540,00 setiap satu kg kerupuk.

Table 6. Analisa Harga Satuan Overhead

\begin{tabular}{lccc}
\hline \multicolumn{1}{c}{ Uraian } & Koef. & $\begin{array}{c}\text { Harga Satuan } \\
(\mathrm{Rp})\end{array}$ & Jumlah (Rp) \\
\hline Overhead : & & & \\
\hline $\begin{array}{l}\text { Bahan bakar } \\
\text { (Sekam) }\end{array}$ & 0,030000 & $18.000,00$ & 540,00 \\
\hline & Jumlah biaya overhead /kg kerupuk & $\mathbf{5 4 0 , 0 0}$ \\
\hline
\end{tabular}

\subsection{Biaya Peralatan}

Biaya peralatan yang dimaksud adalah biaya penyusutan peralatan produksi yang terjadi karena penggunaan peralatan dan menyebabkan penurunan nilai peralatan-peralatan tersebut dalam jangka waktu tertentu. Yang tergolong dalam biaya peralatan ini adalah penyusutan wadah pengaduk, pengaduk, mesin press, cetakan, tempeh, serat kassa, tungku, penutup tungku, media penjemuran, dan timbangan.
Dasar pembebanannya adalah jumlah unit produk yaitu sebanyak $100 \mathrm{~kg}$ kerupuk dalam satu hari. Nilai peralatan mengalami penurunan sesuai dengan pemakainnya dalam proses produksi. Dengan jumlah produksi yang banyak maka nilai penyusutan dari peralatan itu akan ikut tinggi. Jika diakumulasikan sebesar $\mathrm{Rp}$ 43,96 dalam satu kg kerupuk.

Table 7. Nilai Penyusutan Peralatan

\begin{tabular}{lcc}
\hline Uraian & $\begin{array}{c}\text { Nilai } \\
\text { Penyusutan/Th } \\
(\mathrm{Rp})\end{array}$ & $\begin{array}{c}\text { Nilai } \\
\text { Penyusutan/Kg } \\
\text { (Rp) }\end{array}$ \\
\hline Wadah pengaduk & $20.000,00$ & 0,69 \\
\hline Pengaduk & $45.000,00$ & 1,56 \\
\hline Mesin press & $150.000,00$ & 5,21 \\
\hline Cetakan & $24.375,00$ & 0,85 \\
\hline Tempeh & $416.666,67$ & 14,47 \\
\hline Serat kassa & $250.000,00$ & 8,68 \\
\hline Tungku & $50.000,00$ & 1,74 \\
\hline Penutup tungku & $25.000,00$ & 0,87 \\
\hline Media penjemuran & $270.000,00$ & 9,38 \\
\hline Timbangan & $15.000,00$ & 0,52 \\
\hline \multicolumn{2}{c}{ Jumlah penyusutan peralatan /kg kerupuk } & 43,96 \\
\hline
\end{tabular}

Berdasarkan kebutuhan tenaga kerja untuk menghasilkan satu $\mathrm{kg}$ kerupuk dengan menggunakan analisa koefisien peralatan.

Table 8. Analisa Koefisien Peralatan

\begin{tabular}{lccc}
\hline \multicolumn{1}{c}{ Uraian } & $\begin{array}{c}\text { Umur Ekonomis } \\
\text { (Th) }\end{array}$ & Koef./Tahun & Koef./Kg \\
\hline Wadah pengaduk & 10 & 0,100000 & 0,000003 \\
\hline Pengaduk & 2 & 1,000000 & 0,000035 \\
\hline Mesin press & 10 & 0,100000 & 0,000003 \\
\hline Cetakan & 8 & 0,375000 & 0,000013 \\
\hline Tempeh & 3 & 33,333333 & 0,001157 \\
\hline Serat kassa & 2 & 50,000000 & 0,001736 \\
\hline Tungku & 10 & 0,200000 & 0,000007 \\
\hline Penutup tungku & 8 & 0,250000 & 0,000009 \\
\hline Media Jemur & 5 & 3,000000 & 0,000104 \\
\hline Timbangan & 10 & 0,100000 & 0,000003 \\
\hline
\end{tabular}

Biaya peralatan langsung yang dikeluarkan perusahaan sebesar $\mathrm{Rp}$ 43,96 setiap satu $\mathrm{kg}$ kerupuk. 
Table 9. Analisa Harga Satuan Peralatan

\begin{tabular}{lccc}
\hline Uraian & Koef. & $\begin{array}{l}\text { Harga Satuan } \\
(\mathrm{Rp})\end{array}$ & Jumlah (Rp) \\
\hline Peralatan : & & & \\
\hdashline Wadah pengaduk & 0,000003 & $200.000,00$ & 0,69 \\
\hline Pengaduk & 0,000035 & $45.000,00$ & 1,56 \\
\hline Mesin press & 0,000003 & $1.500 .000,00$ & 5,21 \\
\hline Cetakan & 0,000013 & $65.000,00$ & 0,85 \\
\hline Tempeh & 0,001157 & $12.500,00$ & 14,47 \\
\hline Serat kassa & 0,001736 & $5.000,00$ & 8,68 \\
\hline Tungku & 0,000007 & $250.000,00$ & 1,74 \\
\hline Penutup tungku & 0,000009 & $100.000,00$ & 0,87 \\
\hline Media Jemur & 0,000104 & $90.000,00$ & 9,38 \\
\hline Timbangan & 0,000003 & $150.000,00$ & 0,52 \\
\hline Jumlah biaya peralatan /kg kerupuk & $\mathbf{4 3 , 9 6}$ \\
\hline
\end{tabular}

\subsection{Biaya Operasional}

Biaya operasional merupakan biaya yang dapat digolongkan sebagai biaya non-produksi. Biaya operasional dapat dikelompokkan menjadi dua yaitu, biaya administrasi dan umum dan biaya pemasaran. Biaya administrasi dan umum ini merupakan biaya-biaya yang dikeluarkan untuk mengkoordinasikan kegiatan produksi dan pemasaran produk. Biaya pemasaran itu sendiri adalah biaya yang dikeluarkan untuk melaksanakan pemasaran produk. Biaya pemasaran merupakan biaya yang paling penting dikeluarkan perusahaan yang nantinya mempengaruhi posisi atau kedudukan produk di pasaran. Berdasarkan kebutuhan operasional untuk menghasilkan satu kg kerupuk dengan menggunakan analisa koefisien operasional.

Table 10. Analisa Koefisien Operasional

\begin{tabular}{lccrc}
\hline \multicolumn{1}{c}{ Uraian } & Sat. & Vol. & Koef./ Hari & Koef./Kg \\
\hline Adminsitrasi \& Umum & Ls & 1 & 1,000000 & 0,010000 \\
Pemasaran & Ls & 1 & 1,000000 & 0,010000 \\
\hline
\end{tabular}

Biaya keseluruhan dari biaya operasional yang dikeluarkan perusahaan kerupuk ini sebesar Rp 275,00 dalam satu kg kerupuk.

Table 11. Analisa Harga Satuan Operasional

\begin{tabular}{|c|c|c|c|}
\hline Uraian & Koef. & $\begin{array}{c}\text { Harga Satuan } \\
\text { (Rp) }\end{array}$ & $\begin{array}{c}\text { Jumlah } \\
\text { (Rp) }\end{array}$ \\
\hline \multicolumn{4}{|l|}{ Operasional : } \\
\hline Administrasi \& Umum & 0,010000 & $15.000,00$ & 150,00 \\
\hline \multirow[t]{2}{*}{ Pemasaran } & 0,010000 & $12.500,00$ & 125,00 \\
\hline & aya operasi & Ial /kg kerupuk & 275,00 \\
\hline
\end{tabular}

Dari analisa-analisa dengan pengadopsian metode BOW dan Analisa Lapangan yang sudah ada di atas, dapat diolah dan dilanjutkan untuk melakukan perhitungan harga satuan produksi dan penentuan harga jual satuan.

Table 12. Harga Satuan Produksi

\begin{tabular}{|c|c|c|c|}
\hline Koef. & Uraian & $\begin{array}{c}\text { Harga Satuan } \\
\text { (Rp) }\end{array}$ & $\begin{array}{c}\text { Jumlah } \\
\text { (Rp) }\end{array}$ \\
\hline \multicolumn{4}{|c|}{ A. Tenaga } \\
\hline 0,001667 & Mandor & $50.000,00$ & 83,33 \\
\hline 0,010000 & Tukang giling & $40.000,00$ & 400,00 \\
\hline 0,030000 & Tukang cetak & $40.000,00$ & $1.200,00$ \\
\hline 0,010000 & Tukang oven & $40.000,00$ & 400,00 \\
\hline \multirow[t]{2}{*}{0,010000} & Tukang jemur & $30.000,00$ & 300,00 \\
\hline & Jumlah Biaya Tenaga & & $2.383,33$ \\
\hline \multicolumn{4}{|c|}{ B. Bahan } \\
\hline 0,653967 & Tepung terigu & $9.500,00$ & $6.212,68$ \\
\hline 0,006023 & Bawang putih & $33.000,00$ & 198,76 \\
\hline 0,008282 & Bawang merah & $36.000,00$ & 298,14 \\
\hline 0,002981 & Ketumbar bubuk & $20.000,00$ & 59,63 \\
\hline 0,000069 & Merica bubuk & $71.500,00$ & 4,97 \\
\hline 0,023851 & Garam & $2.500,00$ & 59,63 \\
\hline 0,002650 & Kaldu bubuk & $30.000,00$ & 79,50 \\
\hline 0,000706 & Soda kue & $84.500,00$ & 59,63 \\
\hline 0,003313 & Seledri & $12.000,00$ & 39,75 \\
\hline 0,090000 & Air & 210,00 & 18,90 \\
\hline \multicolumn{2}{|r|}{ Jumlah Biaya Bahan } & & $7.031,58$ \\
\hline \multicolumn{4}{|c|}{ C. Overhead } \\
\hline \multirow[t]{2}{*}{0,030000} & Bahan bakar (Sekam) & $18.000,00$ & 540,00 \\
\hline & Jumlah Biaya Overhead & & 540,00 \\
\hline \multicolumn{4}{|c|}{ D. Peralatan } \\
\hline 0,000003 & Wadah pengaduk & $200.000,00$ & 0,69 \\
\hline 0,000035 & Pengaduk & $45.000,00$ & 1,56 \\
\hline 0,000003 & Mesin press & $1.500 .000,00$ & 5,21 \\
\hline 0,000013 & Cetakan & $65.000,00$ & 0,85 \\
\hline 0,001157 & Tempeh & $12.500,00$ & 14,47 \\
\hline 0,001736 & Serat kassa & $5.000,00$ & 8,68 \\
\hline 0,000007 & Tungku & $250.000,00$ & 1,74 \\
\hline 0,000009 & Penutup tungku & $100.000,00$ & 0,87 \\
\hline 0,000104 & Media Jemur & $90.000,00$ & 9,38 \\
\hline 0,000003 & Timbangan & $150.000,00$ & 0,52 \\
\hline & Jumlah Biaya Peralatan & & 43,96 \\
\hline Harg & a Satuan Produksi & $\begin{array}{r}\text { Jumlah } \\
(A+B+C+D)\end{array}$ & $9.998,88$ \\
\hline
\end{tabular}

Langkah selanjutnya dalam setiap usaha adalah menetapkan harga jual. Dalam penetapan harga jual di Lingkungan Mangli Kabupaten Jember saat ini menggunakan penetapan harga jual berdasarkan prosentase operasional dan keuntungan yang diharapkan yaitu sebesar $20 \%$ dari biaya produksi. 
Table 13. Penentuan Harga Jual Satuan

\begin{tabular}{lrrr}
\hline & & Jumlah (Rp) \\
\hline E & Harga Satuan Produksi & Jumlah $(\mathrm{A}+\mathrm{B}+\mathrm{C}+\mathrm{D})$ & $9.998,88$ \\
\hline $\mathrm{F}$ & Operasional + Profit & $20 \%$ & $1.999,78$ \\
\hline $\mathrm{G}$ & Harga Jual Satuan & Jumlah (E+F) & $11.998,65$ \\
\hline \multicolumn{4}{c}{ Terbilang : Dua Belas Ribu Rupiah } \\
\hline
\end{tabular}

Penetapan harga jual pada perusahaan kerupuk di Lingkungan Mangli Kabupaten Jember saat ini cukup memberikan keuntungan yang baik. Sehingga harga jual per satu $\mathrm{kg}$ kerupuk dengan pengadopsian metode BOW dan Analisa Lapangan adalah sebesar Rp 11.998,65 dan dibulatkan sebesar Rp 12.000,00.

\section{Kesimpulan}

Perolehan koefisien dengan mengadopsi metode BOW dan analisa lapangan dapat diterapkan dengan baik, dan menghasilkan keakuratan dalam menentukan harga satuan berdasarkan kebutuhan yang sebenarnya pada masing-masing unsur biayanya. Dalam perhitungan harga satuan dibutuhkan suatu analisa harga satuan, perolehan harga satuan pada masing-masing unsur biaya meliputi harga satuan bahan baku, harga satuan tenaga kerja, harga satuan overhead, harga satuan peralatan, harga satuan operasional, perhitungan harga satuan produksi, serta dalam penentuan harga jual satuan.

\section{Daftar Pustaka}

[1] Mulyadi, Akuntansi Biaya, 5 ed. Yogyakarta: YKPN, 2012.

[2] B. Siregar, B. Suripto, D. Hapsoro, E. W. Lo, dan F. Biyanto, Akuntansi Manajemen, 1 ed. Jakarta: Salemba Empat, 2013.

[3] J. A. Mukomoko, Dasar Penyusunan Anggaran Biaya Bangunan Metode BOW. Jakarta: Gaya Media Pratama, 1986.

[4] J. W. Niron, Pedoman Praktis Anggaran dan Borongan Rencana Anggaran Biaya Bangunan, 9 ed. Jakarta: CV. Asona, 1992.

[5] A. S. Sastraatmadja, Analisa Anggaran Biaya Pelaksanaan. Bandung: Nova, 1984.

[6] I. Bachtiar, Rencana dan Estimate Real of Cost. Jakarta: Bumi Aksara, 1993.

[7] L. M. Samryn, Akuntansi Manajemen, 1 ed. Jakarta: Kencana Prenada Media Group, 2012.

[8] Sugiyono, Metode Penelitian Kuantitatif, Kualitatif dan R\&D. Bandung: Alfabeta, 2016 